(C) Dr W. Junk Publishers, Dordrecht - Printed in the Netherlands

\title{
Population dynamics of Thyasira flexuosa (Bivalvia: Thyasiridae) in inner Galway Bay, West Coast of Ireland
}

Mark Costelloe

Zoology Dept., University College Galway, Ireland

Thyasira flexuosa (Montagu) occurred in high densities over a restricted area of Inner Galway Bay. As part of a broader study being carried out in the bay, the population dynamics of this bivalve were investigated, at a single site, over the two year period November 1982 to October 1984. Monthly sampling (five $0.1 \mathrm{~m}^{2}$ van Veen grabs washed on a $0.5 \mathrm{~mm}$ sieve) revealed a mean population density of $72.6 \pm 42.4 / 0.1 \mathrm{~m}^{2}$.

Recruitment took place between October and July of each year sampled and the growth rate of the $Y_{O}$ year class (1983/'84) was followed from length frequency histograms.

During the course of the study there was a major change in the Thyasira population at the sampling station. From November 1982 to September 1983, the size-frequency structure did not alter greatly, as was the case from November 1979 to April 1981 (Conneely, 1983). In October 1983, the numbers fell dramatically, but a similar drop had been noted in February 1983 and it was assumed that this reflect- ed a patchiness in the bivalves microdistribution. In January 1984, however, numbers were down again on the previous months and this intensified to a point in October 1984 where the majority of individuals recovered were those that had settled in the previous months.

The reasons for this population crash are, as yet, unknown. Temperature and salinity data over the sampling period show the same seasonal trend since 1979. Sediment data, on the other hand, did indicate some change.

This work is continuing and the crash of $T$. flexuosa will be viewed in context of the returns for the total macrofauna over the same study period.

\section{References}

Conneely, M. E., 1983. Benthic ecological studies in Inner Galway Bay (West Coast of Ireland) with particular reference to Bivalvia. (Unpubl. Ph.D. Thesis). University College Galway. National University of Ireland, 144 pp. 